Urszula K. Zawadzka-Pąk

University of Biatystok

\title{
PERFORMANCE BUDGETING AND THE MULTIANNUAL PROGRAMMING OF PUBLIC FINANCES ${ }^{1}$
}

\section{Introduction}

Generally performance budgeting is considered as a method of improving the effectiveness (quality of public services), the efficiency (understood as the ratio of expenditures to the obtained results) and the transparency of public tasks realisation (providing to citizens comprehensible information on the functioning of public administration). However, the multiannual aim of the application of performance budgeting should also consist of strengthening real convergence with the developed countries, by achieving and maintaining high rates of economic growth ${ }^{2}$. To achieve this goal it is necessary to link performance budgeting with multiannual planning (programming). For this reason, the principle of multiannuality has become one of the basic principles of performance budgeting ${ }^{3}$.

Despite past attempts to extend the planning period of the budget, modern state financial management is still based on the annual budget voted in the form of a budgetary (or financial) act. On the other hand, multiannual plans that enable the reflection on planned expenditures in the horizon exceeding a period of one year have recently started to play a more important role in making decisions on the allocation of public funds.

Due to the nature of performance budgeting and its features distinguishing it from the traditional one (described in subsection 2), the link between performance budgeting and multiannual programming in principle can be carried out in two ways. Firstly, by extending the planning horizon of the annual budgetary (or financial) acts and its accompanying documents (see subsection 3 ) and secondly, by preparation

\footnotetext{
1 This Article was prepared within the framework of the project financed by the National Science Centre granted on the basis of decision no. DEC-2011/01/B/HS5/03357.

2 M. Postuła, P. Perczyński, Budżet zadaniowy - wprowadzenie; znaczenie wieloletniego planowania strategicznego w procesie budżetowania, Warszawa 2010, p. 34.

3 T. Lubińska, Budżetowanie zadaniowe w kontekście zasad podatkowych i budżetowych, in: S. Wieteska M. Wypych (eds.), W poszukiwaniu efektywności finansów publicznych, Łódź 2009, p. 88.
} 
of the multiannual plans that are separate from the budgetary (financial) act (see subsection 4).

\section{Essence of Performance Budgeting}

The precise explanation of the nature of performance budgeting ${ }^{4}$ firstly requires identification of the fundamental differences between the traditional budget and the performance one, as it enables the clarification of the relationship between performance budgeting and multiannual programming. Therefore, the main differences between the traditional budget and the performance one concern:

- the classification of expenditures - the traditional budget is based on parts, sections, chapters and paragraphs that have heterogeneous character (expenditures are divided on the basis of the entity or the subject criterion), whereas in the case of performance budgeting, expenditures are classified by function, tasks, sub-tasks and actions distinguished only on the basis of the financing subject criterion ${ }^{5}$. It should be noted that the introduction of performance budgeting does not cause any changes in the revenue side of the budget;

- the performance part of the budget - is an essential tool to assess the efficiency and effectiveness of the execution of the performance budget consisting of the objectives and indicators that enable the measurement of the effects of public spending. This performance part does not exist in the traditional budget;

- the control criteria - in the traditional budget emphasis is placed on the legality of expenditure and revenue collection, while in the performance budget, beyond compliance with the law, the effectiveness and the efficiency of public administration activity is evaluated;

- managerial autonomy - is one of the sine qua non conditions of the success of performance budgeting. It consists, according to public managers, of much larger freedom (autonomy) in making decisions on the use of budgetary resources. In return, however, they are expected to improve the efficiency and effectiveness of the execution of public tasks. The results of their work are assessed by realisation of the objectives that are measured by indicators;

- the planning horizon - the traditional budget is generally of annual character, whereas having implemented the performance budget the planning horizon is extended.

\footnotetext{
$4 \quad$ In some countries the terms "performance budget" and "performance budgeting" are used interchangeably, while the first one is related to a plan that satisfies the determined conditions and the latter one should be treated as a method of budgeting.

5 The nomenclature used to describe the levels of functional classification is sometimes different in particular countries, however, the general principles of the expenditure classification are almost the same.
} 
Secondly, precise definition of the ,performance budget” requires distinction between the budget as a legal institution and as an economic one ${ }^{6}$. The state budget in its legal terms is a plan that has particular legal form (budgetary or financial act), the special legal force (authorisation to collect revenues and make expenditures) and the specific period of validity (one year).

On the basis of the above-mentioned characteristics which distinguish the performance budget from the traditional one, it needs to be highlighted that the performance budget in legal terms is a financial and material plan [enacted in the form of the budgetary (financial act)], which authorises for the period of one year to collect the revenues and to make expenditures. The expenditures are classified in accordance with the functional classification and evaluated with the performance objectives and indicators.

In turn, the state budget in its economic terms should be regarded as a centralised fund of financial resources that are collected by the state and used in a planned way to carry out its tasks ${ }^{7}$. Assuming that the state budget is an economic category, there are no contraindications to consider the performance budget as the set of information on planned results of the determined financial fund, where the expenditures are classified in accordance with the functional classification and evaluated with the performance objectives and indicators. ${ }^{8}$

\section{Relations Between Performance Budgeting and Multiannual Programming}

As indicated in the introduction, the linkage between performance budgeting and multiannual programming can be done in two ways. The first - described in this sub-section - consists of the extension of the planning horizon of the (annual) budgetary (financial) act. It can be achieved through the implementation of the multiannual programs planned in the budgetary (financial) act or through the planning performance indicators in the multiannual horizon.

As an example of the first possibility one should examine the Polish solutions where multiannual programs are presented in the Budget Act (beyond the "typical" performance budget inserted in the justification of the budget bill ${ }^{9}$ ). Multiannual programs - due to the fact that they have been extracted from the actions (eventually sub-tasks or tasks) of the performance budget and therefore represent only a part

6 For more details about the differences between the performance budget in legal and economic sense see: U.K. Zawadzka-Pąk, Polish Financial Law, Bialystok 2014 (in press).

7 E. Ruśkowski, C. Kosikowski (eds.), Finanse publiczne i prawo finansowe, Warszawa 2008, p. 301.

8 OECD, Modernising Government. The way forward, Paris 2005, p. 59.

9 In Poland the traditional budget still constitutes the budget in its legal terms, while the performance budget in an economic sense is presented in the governmental justification of the budget bill. The functional expenditures classification consists of four levels: functions (the highest one), tasks, sub-tasks and actions. The information on the realisation of the performance budget is presented in the governmental report. 
of them - are in most cases fulfilled by only one ministry. The interdepartmental programs are hardly ever planned, whereas with the performance budget, a significant proportion of the tasks budget is interdepartmental).

The values of indicators of multiannual programs are planned for a period of three years. The spending prognosis in principle is planned for a period of the same three years as well, however, in some cases the expenditures are indicated only for the upcoming budgetary year. Regardless of the expenditure planning horizon in multiannual programs (one or three years), the Budgetary Act authorises to make expenditures only for one year. Thus, the presentation of multiannual expenditures prognosis in the Budgetary Act (or its annexes) for the second or third year of the program realisation does not constitute the grounds to demand obtaining the prescheduled amount in the coming years. ${ }^{10}$

As indicated above, the vast majority of multiannual programs in Poland correspond to actions (the lowest level of the Polish functional classification) of the performance budget, eventually multiannual programs were extracted from these actions, so they constitute only its part. The adoption of such a solution causes that the exploitation of the multiannual programs enables to implement actions (usually the investments ones) in the next few years, but does not make it possible to coordinate the realisation of the tasks having similar objectives entrusted to several ministries ${ }^{11}$.

Such a possibility exists, however, in France, where the "interdepartmental performance programs" constructed on the basis of the task of the performance budget are realised. The tasks in the French performance budget are always implemented by only one ministry, which allows to avoid problems of the "blurring" of responsibility between several ministers for the realisation of the planned objectives, and the institution of interdepartmental performance programs enables to coordinate the tasks with similar objectives to avoid financing the same objectives from different sources.

In turn, a slightly different solution has been applied in Slovakia, where two types of tasks have been distinguished in the structure of the performance budget, i.e. the timely determined tasks and the timely undetermined ones. The first of them has a starting and an ending date. The degree of its realisation is evaluated by means of objectives and indicators during the realisation period. In turn, the timely undetermined tasks are realised by the institutions whose tasks do not change significantly during the period of their validity. Its realisation is mainly assessed with the binary (yes/no) indicators which in fact do not describe task execution. The final evaluation of the timely undetermined tasks is strictly formal, since its purpose is to ensure the continuity of operations, which mainly arise from statutory obligations.

\footnotetext{
10 U.K. Zawadzka-Pąk, Commentary to Art. 122 of PFA, in: E. Ruśkowski, J.M. Salachna (eds.), Finanse publiczne 2014. Komentarz praktyczny, Gdańsk 2014, p. 542.

11 U.K. Zawadzka-Pąk, Konstrukcja prawna Konstrukcja prawna, wdrażanie i realizacja budżetu zadaniowego we Francji i w Polsce, Kraków-Legionowo 2014, pp. 91-95.
} 
The responsibility for the realisation of these two types of tasks is conferred on singular ministers. Additionally, in the Slovak system of performance budgeting the interdepartmental performance programs are realised as well. Its implementation is coordinated by one of the ministers realising the program, whereas the other institutions involved in its execution realise the particular sub-programs. ${ }^{12}$

The second option to link the annual performance budgeting and the multiannual programming consists of the extension of the planning horizon of indicators used in the performance budget. The values of indicators can be planned only for the following year (such a solution is often used in the first years of implementation of performance budgeting, i.e. in the phase of learning mechanisms of its application), or for several years. For example, in Poland, the values of indicators were initially planned only in annual horizon, whereas nowadays they are planned for a few following years.

The situation is quite different in France, where since the introduction of the performance budget, the indicators have been planned in the multiannual perspective. Its values are published in the PAP plans (fr. projet annuel de performance) prepared separately for each function. In turn, the reports on the implementation of these plans are published in the RAP reports (fr. rapport annuel de performance) that have the analogues structure as the PAP plans ${ }^{13}$. In France, for every indicator not only are the planned values for several years presented (as it happens currently also in the Polish performance budget), but also the values that had been planned in the past for the future (to illustrate the quality of the planning of improving the efficiency and effectiveness of public service delivery) and the results achieved in the previous years (to illustrate the progress which had already been done).

\section{Relations Between Performance Budgeting and Multiannual Financial Plans}

In recent years (even before Directive 2011/85/EU ${ }^{14}$ requiring the EU states to prepare multiannual financial plans entered into force), many countries started to develop their own plans aiming at ensuring multiannual sustainability of its public

12 Ministerstwo Finansów, Opracowanie dotyczące wizyty przedstawicieli Ministerstwa Finansów na Słowacji, której celem było zapoznanie się z funkcjonowaniem i rozwojem słowackiego budżetu zadaniowego i wieloletniego planowania wydatków, w kontekście przystąpienia Słowacji do strefy Euro, Warszawa 2009, p. 8.

13 The obligation to prepare the PAP plans and the RAP reports arises from the regulations of Organic Law on Finance Laws of 2 August 2001 (commonly referred as LOLF), while there are no references to them in the Financial Act (containing the annual state budget). Under financial laws the limits of tasks belonging to different functions are determined, as well sub-limits of persons expenditures of each task. The estimated division of other groups of expenditures (e.g. the capital expenditures, the intervention ones), as well the performance part of the budget (i.e. objectives and indicators) are presented in PAP plans that are non-binding from a financial point of view.

14 Council Directive 2011/85/EU of 8 November 2011 on requirements for budgetary frameworks of the Member States (OJ L 306 of 23.11.2011, p. 41), hereinafter referred to as the Directive 2011/85/EU. EU Member States were obliged to implement it by 1 January 2014. 
finances. In some countries, these plans are linked to the existing annual performance budgets (e.g. France), while in others there is no reference to performance budget in the multiannual financial plans (e.g. Hungary).

In this regard special attention should be paid to the solutions implemented in Poland, especially due to the latest changes in the Polish Public Finance Act (PFA) ${ }^{15}$ that entered into force on 1 January 2014. In Poland the multiannual programming at the central level is realised via the institution of Multiannual Financial State Plan (pl. Wieloletni Plan Finansowy Państwa, WPFP). The first four plans (i.e. for the periods: 2010-2013, 2011-2014, 2012-2015, 2013-2016 ${ }^{16}$ ) specified the objectives of the socio-economic policy and the fiscal one, the forecasts of public debt, the basic data on the state budget. Additionally, these plans also had to include the attachment where every function (the highest level of functional expenditures classification) of annual performance budget was described in multiannual perspective (i.e. description of function, its objectives and indicators, the values of indicators planned separately for each of four years of programming, as well as planned expenditures for the following year and for the last three years of programming).

The WPFP plan for the period 2014-2017, currently in force, approved by the Council of Ministers in April 2014, consists of the Convergence Programme (presented annually to the European Commission) and a surely synthetic description of the objectives of the main functions of the state together with indicators of its realisation (in general, only the value achieved at the beginning of 2014 and the value planned for 2017 are presented).

In France as well, in a result of the adjustment of national legislation to EU regulations (especially to the provisions of Directive 2011/85/EU), some modifications in the content of its multiannual financial plans, i.e. in acts on public finance programming (fr. loi de programmation des finances publiques) were made. This category of law had been introduced into the French legal system as the result of the 23 July 2008 Amendment to the French Constitution. Nowadays, according to the constitutional legislator, the acts on public finance programming define the objectives of the actions of the state and the multiannual directions of public finances, and are used to achieve the aims of balancing the accounts of public administrations (Art. 34 of the French Constitution).

The first two acts on public finance programming (i.e. 2009-2012 ${ }^{17}$ and 2011$2014^{18}$ ) were issued only on the basis of the above quoted, very general dispositions

15

Ustawa z dnia 29 sierpnia 2009 r. o finansach publicznych (Dz.U. №157 item 1240 as amended), hereinafter referred to as PFA.

Interestingly enough, the provisions of PFA (prior to the above-mentioned amendment that came into force on 1 January 2014) obliged the government to update the WPFP annually to adapt its content to the Budget Act calling into question the idea of multiannual financial planning.

Loi $n^{\circ} 2009-135$ du 9 février 2009 de programmation des finances publiques pour les (JORF n³5 du 11 février 2009).

Loi $n^{\circ} 2010-1645$ du 28 décembre 2010 de programmation des finances publiques pour les années 2011 à 20142014 (JORF n³01 du 29 décembre 2010). 
of Art. 34 of the Constitution, and therefore the decisions and the special needs of the government (rather than the legal provisions) affected the material scope of these acts. The situation changed with the entry into force of the organic law on the programming and management of public finances of 18 December $2012^{19}$, which precisely determines the content of the acts on public finance programming.

On 31 December 2012, the third act on public finance programming for the period of 2012-201720 was adopted. It contains, for example, three fiscal rules, namely the rule of balance of the public finance sector, the expenditure rule and the debt rule (however, none of them has the character of the golden rule). Additionally, this act (similarly as the previous ones) contains a three-year expenditure plan of functions representing the highest level of French (annual) performance budget. However, there are neither objectives nor indicators of functions therein.

\section{Conclusions}

As the researches have shown, planning public revenues even in annual perspective ${ }^{21}$ poses many difficulties, especially due to the need of taking into account certain macroeconomic phenomena, while without reliable revenues estimations it is not possible to plan expenditures. Obviously, the process of planning in a multiannual perspective is much more complicated. However, despite the complexity of multiannual programming, the consequences of the latest global financial and economic crisis have highlighted that multiannual programming is one of the sine qua non conditions of financial sustainability.

Also, performance budgeting, properly implemented and used, due to its role of improving the effectiveness and the efficiency of public spending also constitutes a tool to reinforce the stability of public finances. Therefore, the crucial thing is to profit from the synergy effect resulting from the effective combination of both instruments, i.e. performance budgeting and multiannual planning (bearing in mind that at times these tools may in some aspects be contradictory $)^{22}$.

19 Loi organique $\mathrm{n}^{\circ} 2012-1403$ du 17 décembre 2012 r.elative à la programmation et à la gouvernance des finances publiques (JORF n²94 du 18 décembre 2012).

20 Loi n²012-1558 du 31 décembre 2012 de programmation des finances publiques pour les années 2012 à 2017 (JORF $\mathrm{n}^{\circ} 1$ du 1 janvier 2013).

21 For example, in Poland the divergence between the revenues forecasts and its executions in the last decade are as follows: $2000:-3,7 \%, 2001:-12,8 \%, 2002:-1,1 \%, 2003:-2,3 \%, 2004:+1,1 \%, 2005:+2,9 \%, 2006:+1,2 \%$, 2007: $+3,2 \%, 2008:-10,1 \%, 2009:-9,5 \%, 2010:+0,5 \%, 2011:+1,6 \%, 2012:-6,2 \%$. For more details on the difficulties in the process of the budgetary revenues planning see: U.K. Zawadzka-Pąk, The Reality of Planning of Budgetary Revenues in Poland - Facts, Reasons, Consequences, Journal of Voronez State University, Woronez 2014 (in press).

22 For more details concerning the relations between performance budgeting and multiannual financial planning see: U.K. Zawadzka-Pąk, Budżetowanie zadaniowe a programowanie wieloletnie finansów publicznych, in: E. Ruśkowski (ed.), Roczność i wieloletniość w finansach publicznych, Warszawa 2014 (in press). 


\section{BUDŻET ZADANIOWY A PROGRAMOWANIE WIELOLETNIE W FINANSACH PUBLICZNYCH}

Ostatni kryzys finansowy i gospodarczy unaocznił, jak ważne jest podjęcie skutecznych działań umożliwiających wzmocnienie stabilności finansów publicznych. W tym celu niezwykle istotne jest wykorzystanie zarówno budżetowania zadaniowego jak i planowania (programowania) wieloletniego, a także efektu synergii powstałego na skutego jednoczesnego zastosowania obu tych instrumentów. Ze względu na istotę budżetu zadaniowego i określone jego cechy odróżniające go od budżetu tradycyjnego powiązanie planowania zadaniowego z programowaniem wieloletnim może następować co do zasady w dwojaki sposób. Po pierwsze poprzez wydłużenie horyzontu planowania w (rocznej) ustawie budżetowej (finansowej) oraz w dokumentach jej towarzyszących, po drugie zaś poprzez opracowywanie odrębnych od budżetu planów o charakterze wieloletnim odwołujących się jednak do aktu autoryzującego do dokonywania wydatków, tj. ustawy budżetowej (finansowej).

Słowa kluczowe: budżetowanie zadaniowe, wieloletnie planowanie finansowe, mierniki, Polska, Francja, Słowacja

Keywords: performance budgeting, multiannual planning, financial programming, indicators, Poland, France, Slovakia 